Research Article

\title{
Water Distribution in Reconstructed Soil of Nonmetal Mines and the Ecological Effect in Xinjiang, China
}

\author{
Zizhao Zhang, ${ }^{1,2}$ Xiaoli Guo $D^{3},{ }^{3}$ Qianli Lv, ${ }^{1}$ Ruihua Hao, ${ }^{1}$ Zezhou Guo, ${ }^{1}$ XueBang Huang, \\ and Zekun Guo ${ }^{1}$ \\ ${ }^{1}$ School of Geological and Mining Engineering, Xinjiang University, Urumqi, Xinjiang, China \\ ${ }^{2}$ State Key Laboratory for Geomechanics and Deep Underground Engineering, Xinjiang University, Urumqi, Xinjiang, China \\ ${ }^{3}$ Xinjiang Intelligent Check for Security Environmental Protection Technology Co.,Ltd., Urumqi, Xinjiang, China
}

Correspondence should be addressed to Xiaoli Guo; 39755581@qq.com

Received 13 August 2020; Accepted 8 December 2020; Published 23 December 2020

Academic Editor: Francesco Ruffino

Copyright ( 92020 Zizhao Zhang et al. This is an open access article distributed under the Creative Commons Attribution License, which permits unrestricted use, distribution, and reproduction in any medium, provided the original work is properly cited.

Because of the arid climate and fragile ecological environment in Xinjiang, China, land reclamation should be carried out after mining. The core of land reclamation is the water content of the surface covering soil. In this paper, the law of water distribution in reclamation reconstructed soil of nonmetal mines in Xinjiang was studied. In order to obtain the law of water distribution in reconstructed soil, we set up an observation system of the neutron probe and tensiometer. The neutron probe was used to monitor the soil water content. The tensiometers were used to obtain the matrix potential of soil for verifying the water distribution in reconstructed soil. Volumetric water content and matrix potential of reconstructed soil during 1-year period of management and irrigation were obtained by long-term monitoring. After one year's field in situ test, 2424 sets of neutron probe data and 1368 sets of tensiometer data were obtained. By studying the above parameters, we summarized the law of water distribution in reconstructed soil of variable thickness and degree of compaction with nonmetallic waste rock filling. The results showed that covering soil was helpful to retain water content. Whether the soil was compacted or uncompacted, the soil water content at the depth of $10 \mathrm{~cm}$ was less than that at other depth of reconstructed soil because it was greatly affected by meteorological factors. The water content of reconstructed soil at $30 \mathrm{~cm}$ depth was greater than that at other depths. Under the influence of factors such as the thickness and compaction of the soil, the response time of soil water content and matrix potential to each irrigation infiltration was different. According to the characteristics of reclamation-vegetation such as alfalfa growth in Xinjiang, the thickness of surface reconstructed soil should be not less than $50 \mathrm{~cm}$. Over time, soil that was compacted once was better for the vegetation. The research results could provide a reference for the land reclamation of nonmetallic mines in Xinjiang, China.

\section{Introduction}

There are abundant nonmetallic mineral resources in the Xinjiang Uygur Autonomous Region. Mining of mineral resources is conducive to the development of the local economy. However, substantial damage has been done to the local environment because of large-scale exploitation. In Xinjiang, the ecological environment is fragile, so it is necessary to carry out geological environment control and land reclamation after mines are closed. Covering soil is an important measure to restore surface vegetation. Due to the arid climate in this area, in order to ensure the survival rate of vegetation after reclamation, a one-year management and irrigation period is set up. During this period, the water content of reconstructed soil will directly affect the growth of vegetation, so it is necessary to carry out the research on the law of water distribution of reconstructed soil during the management and irrigation period.

There are many factors affecting water distribution in reconstructed soil, among which the reclamation method [1] and soil compaction [2] are two important aspects. The methods used to analyze reconstructed soil water characteristics included ground-penetrating radar [3], soil column experiments $[4,5]$, neural network analysis [6], field test 
[7-10], numerical simulation analysis [11], cosmic ray probes [12], and X-rays [13]. Davies et al. [14] found that the water content and bulk density of reconstructed soil were higher than those of natural soil, whereas the infiltration rate was lower than natural agricultural soil. The research results [15-18] have shown that when using fly ash as the fill matrix for reconstructing soil, there is a difference between its capacity for water and the capacity of natural soil.

In the past $[3-5,12,19-23]$, the research on reconstructed soil water distribution in mining areas was mainly carried out under specific conditions (the lower part of the soil was mainly backfilled with fly ash and coal gangue). However, the lower part of reconstructed soil in the nonmetal mining area is backfilled with large waste rocks such as limestone, dolomite, granite, and marble. The hydraulic parameters such as porosity and hydraulic conductivity are notably different from those of fly ash and coal gangue. In Xinjiang, the soil is generally sandy soil. Up to now, there have been few studies on the water distribution in the unsaturated zone of sandy soil backfilled with nonmetallic mineral waste rock under the condition of drought climate and irrigation infiltration during the period of management and protection for land reclamation.

In this paper, given the limitations of previous studies and the typically sandy soil on the surface of nonmetallic mines in this area, the parameters such as volumetric soil water content and matrix potential of reconstructed soil during one-year management and irrigation period were obtained by the method of field in situ test and dynamic monitoring, and the law of water distribution in reconstructed soil with different thickness and compaction under the condition of waste rock filling was summarized.

\section{Materials and Methods}

2.1. Test Materials. The test of dynamic observation of reconstructed soil water distribution was conducted at the Changji groundwater balance test field in Xinjiang. The test soil was taken from a limestone mining area in Dabancheng, Urumqi, Xinjiang. The test soil was brown calcium sandy soil with a bulk density of $12.646 \mathrm{kN} / \mathrm{m}^{3}$, a porosity of $57.71 \%$, and a volumetric water content of $11.76 \%$. The lower part of the reclamation soil was backfilled with waste rock from this limestone mining.

2.2. Test Design. Based on local experience, the thickness of the surface soil for mine land reclamation in Xinjiang is generally set at $30-70 \mathrm{~cm}$. In this test, a total of 6 test barrels were used for the experiment. There were two groups, with surface soil thicknesses of 30,50 , and $70 \mathrm{~cm}$. The first group was not compacted, the second group was compacted once using a bulldozer, and the serial numbers of these test barrels are shown in Figure 1. During the experiment, irrigation was applied based on the normal irrigation amount and frequency for an artificial grassland in this area during the period of management and protection. The observation period was one year (from August 5, 2016, to August 6, 2017). A system of neutron probes and tensiometers was established. The test site was equipped with a meteorological station, which was used to measure the ground-based meteorological data including precipitation, evaporation, wind direction, wind speed, and temperature. The field test data were processed, and the water distribution in the reconstructed soil was analyzed.

2.3. Test Method. The neutron probe was used to determine the water content of the reconstructed soil at different depths. The iron tubes and stainless steel tubes were preplaced in the six barrels to be tested, and the data from these tubes were compared with that of an aluminum tube. Tensiometers were buried according to the thickness of the covering soil. Tensiometers were installed at depths of $10 \mathrm{~cm}$ and $30 \mathrm{~cm}$ for soil $30 \mathrm{~cm}$ thick, at 10,30 , and $50 \mathrm{~cm}$ for soil $50 \mathrm{~cm}$ thick, and at $10,30,50$, and $70 \mathrm{~cm}$ for soil $70 \mathrm{~cm}$ thick. The arrangement of tensiometers and neutron probes is shown in Figures 2 and 3.

The test was started after the relevant preparations were completed. The observations began on August 5, 2016. Watering was applied in accordance with the standard value of $240 \mathrm{~m}^{3} / \mathrm{hm}^{2}$ for reclamation of grasslands in Xinjiang. The irrigation amount was based on a soil thickness of $50 \mathrm{~cm}$. In the test barrels, $28.8 \mathrm{~L}$ of water was applied to the barrels with a soil thickness of $30 \mathrm{~cm}$ (equivalent to $14.4 \mathrm{~mm}$ rainfall), $48 \mathrm{~L}$ of water was applied to the barrels with a soil thickness of $50 \mathrm{~cm}$ (equivalent to $24 \mathrm{~mm}$ rainfall), and $67.2 \mathrm{~L}$ of water was applied to barrels with a soil thickness of $70 \mathrm{~cm}$ (equivalent to $33.6 \mathrm{~mm}$ rainfall). Three watering times were set for the one-year period: August 7, September 8, and October 4, 2016. In the first month, after the start of the test, observations were conducted daily. After the first month, interval observations (2-4 times per week) were initiated. In special circumstances such as rainfall and irrigation, the observation frequency was increased appropriately. The daily observation times were 8 p.m. in the summer and autumn and 6 p.m. in winter and spring. Because the temperature in this area decreases sharply at the end of October each year, to prevent the tensiometers from being damaged by low temperature, the observations using tensiometers were stopped from October 31, 2016, to April 22, 2017; during this period, only the observation data from the neutron probes were available.

2.4. Arrangement of Test Data. After one year of observations, 2424 sets of neutron probe data and 1368 sets of tensiometer data were obtained.

2.4.1. Processing of Neutron Probe Data. Since the data read by the neutron probe are the number of neutrons, conversion into volumetric water content requires the use of a calibration equation. Based on the previous research results in this test field, a set of calibration equations (Table 1) for the soil layer profile was established.

The correlation analysis of 360 sets of neutron probe data from the stainless steel tube, iron tube, and aluminum tube showed that the correlation between the stainless steel tube 

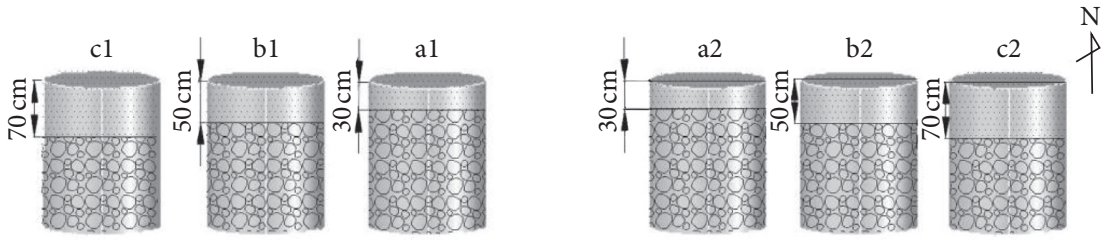

Figure 1: Schematic diagram of 6 test barrels. Note: "a" represents the covering soil with a thickness of $30 \mathrm{~cm}$, "b" represents the covering soil with a thickness of $50 \mathrm{~cm}$, " $\mathrm{c}$ " represents the covering soil with a thickness of $70 \mathrm{~cm}$, "1" represents that the topsoil is not compacted, "2" represents that the topsoil is one time compacted, and "al" represents that the soil with a thickness of $30 \mathrm{~cm}$ is not compacted. The meaning of the subsequent test barrel number is the same.
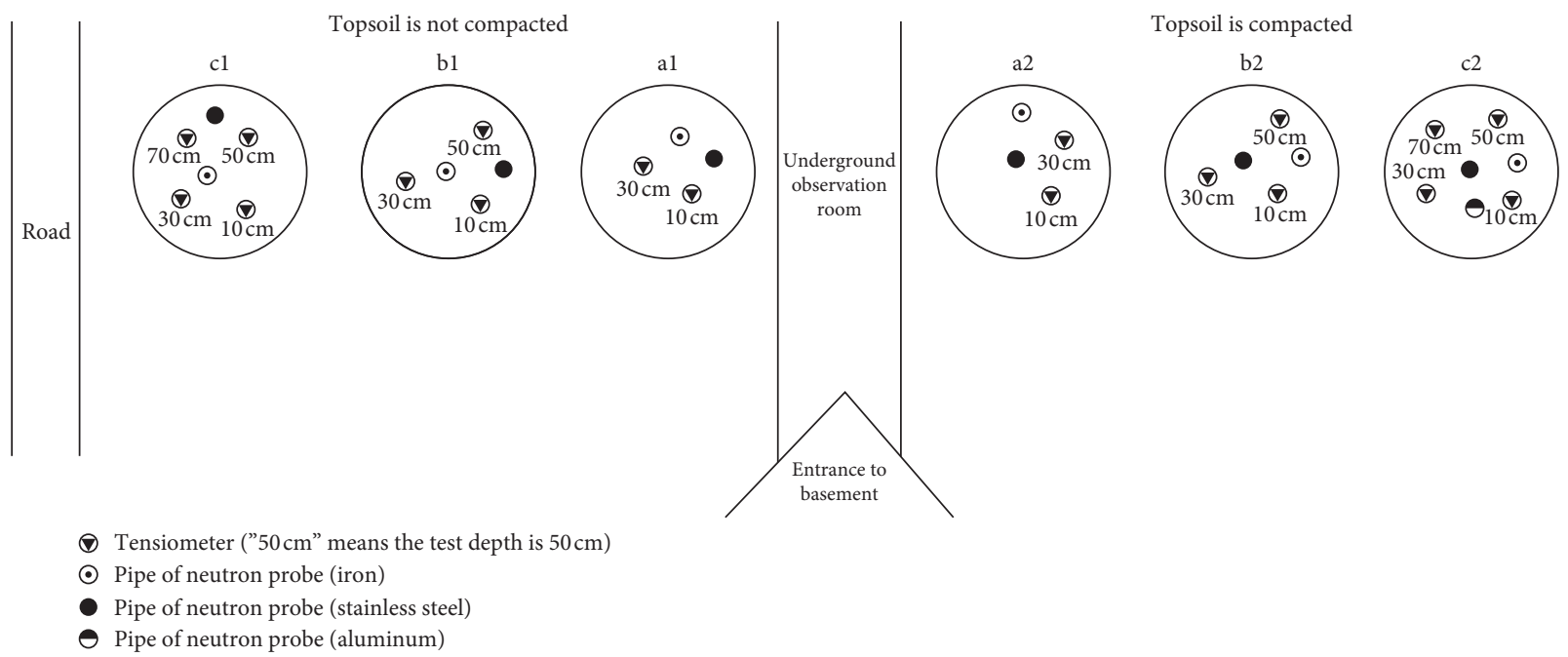

FIgURE 2: Layout chart of tensiometers and neutron probes.

b1

a1

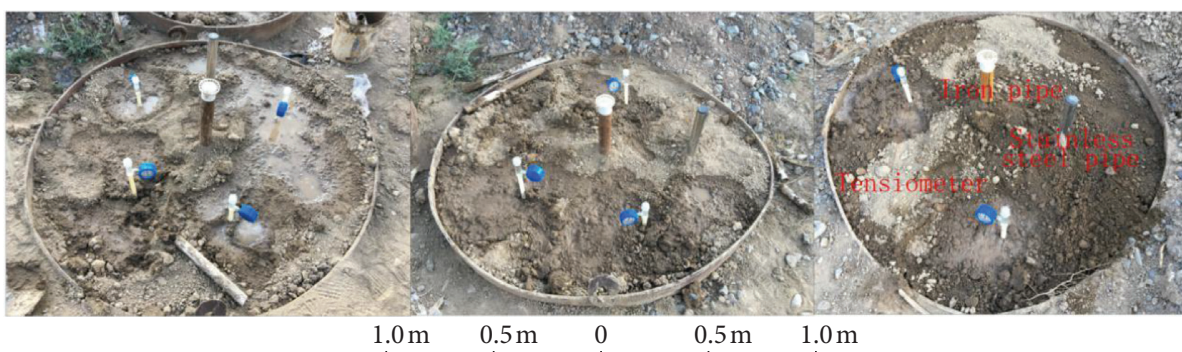

b2

c2

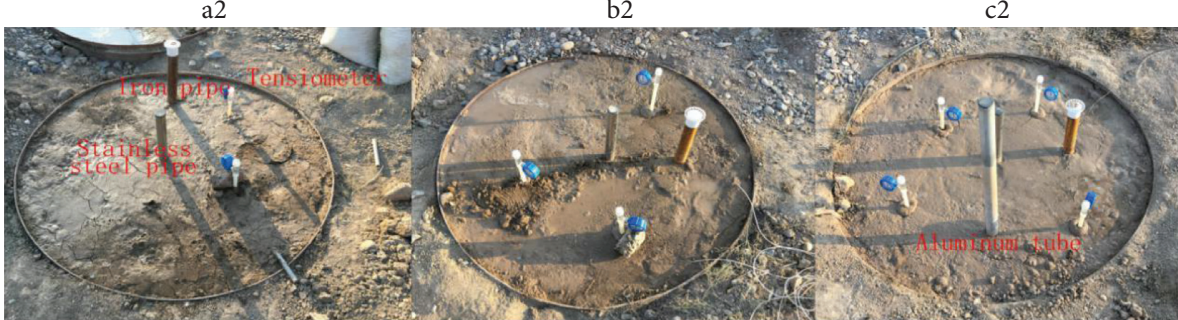

$1.0 \mathrm{~m} \quad 0.5 \mathrm{~m} \quad 0 \quad 0.5 \mathrm{~m} \quad 1.0 \mathrm{~m}$

Figure 3: Test barrels.

and the aluminum tube was good. When calculating the volumetric soil water content, the neutron probe data from the stainless steel tube were used for the calculation.
2.4.2. Meteorological Data. The meteorological data included barometric pressure, temperature, precipitation, evaporation, humidity, sunshine time, and wind speed. 
TABLE 1: Calibration equation of neutron probe in the soil.

\begin{tabular}{lccc}
\hline Serial number & Instrument model of neutron probe & Depth of measurement $(\mathrm{cm})$ & Calibration equation \\
\hline 1 & & 10 & $\theta=7.12+49.61 \times(R / R \omega)$ \\
2 & L-520D & 30 & $\theta=5.071+58.224 \times(R / R \omega)$ \\
3 & & $\geq 40$ & $\theta=-0.83+58.102 \times(R / R \omega)$ \\
\hline
\end{tabular}

$\Theta$, volumetric soil water content (\%); $R$, average of neutron readings at different depths of soil (counts/s); $R \omega$, calibration number of neutron probe (counts/s).

During the test period (August 5, 2016, to August 5, 2017), the total precipitation was $134.8 \mathrm{~mm}$, the evaporation was $1147.1 \mathrm{~mm}$, and the average temperature was $7.66^{\circ} \mathrm{C}$. The statistical curves of precipitation and evaporation are shown in Figure 4.

\section{Results}

\subsection{Water Distribution of Uncompacted Soil}

\subsubsection{Water Distribution of the Reconstructed Soil with a Thickness of $30 \mathrm{~cm}$}

(1) Transformation Law of Water Content. During the test, the volumetric soil water content with a thickness of $30 \mathrm{~cm}$ could be roughly divided into two sections (Figure 5(a)). One is that the water content was between 0.25 and 0.4 , which was at the depth of $30 \mathrm{~cm}$, and the other was that the water content was between 0.13 and 0.2 , which was at the depth of $10 \mathrm{~cm}, 50 \mathrm{~cm}, 70 \mathrm{~cm}$, and $90 \mathrm{~cm}$. Because the medium in the test barrel was a dual structure of upper fine and lower coarse, the water holding capacity of the covering soil was strong, and the soil water content at the depth of $30 \mathrm{~cm}$ was greater than that at the depth of $50 \mathrm{~cm}, 70 \mathrm{~cm}$, and $90 \mathrm{~cm}$. The reason why the soil water content at the depth of $10 \mathrm{~cm}$ was less than that at the depth of $30 \mathrm{~cm}$ was that the surface soil was greatly affected by evaporation. During the test, the water content of covering soil $(10 \mathrm{~cm}$ and $30 \mathrm{~cm}$ deep) was obviously related to rainfall and irrigation.

In order to analyze the change in soil water content before and after irrigation, the response of soil water content to irrigation is plotted in Figure 5(b). As can be seen from this figure, on August 6, 2016, the soil water content at the depth of $10 \mathrm{~cm}$ was $0.16 \mathrm{~cm}^{3} / \mathrm{cm}^{3}$. After irrigation on August 7,2016 , the soil water rapidly infiltrated, and the soil water content at the depth of $10 \mathrm{~cm}$ increased from $0.177 \mathrm{~cm}^{3} \mathrm{~cm}^{-3}$ on August 7, 2016, to $0.181 \mathrm{~cm}^{3} \mathrm{~cm}^{-3}$ on August 8, 2016, and reached the maximum of this depth. At the same time, at the depth of $30 \mathrm{~cm}$, the soil water content reached the maximum on August 8, 2016. With the downward movement of the wetting front, the soil water content at the depth of $30 \mathrm{~cm}$ gradually decreased. By August 15, 2016, the soil water content was less than that on August 6, 2016; that is to say, the infiltration process of this irrigation in covering soil was completed, lasting for 9 days.

(2) Transformation Law of Matrix Potential. During the observation period, the matrix potential values at the depth of $10 \mathrm{~cm}$ and $30 \mathrm{~cm}$ ranged from $3 \mathrm{~cm}$ to $90 \mathrm{~cm}$ and $5 \mathrm{~cm}$ to $85 \mathrm{~cm}$, respectively. Generally, due to the influence of meteorological factors, during the nonirrigation period, the surface soil was dry, and the matrix potential values of $10 \mathrm{~cm}$ depth were greater than that of $30 \mathrm{~cm}$, which was consistent with the observation response of water content. At the same time, it could be seen that the effect of irrigation on matrix potential was greater than that of precipitation (Figure 5(c)).

From Figure 5(d), we can see the matrix potential change in soil profile after one irrigation. After irrigation, the matrix potential of soil decreased dramatically, from $29 \mathrm{~cm}$ to $3 \mathrm{~cm}$ at $10 \mathrm{~cm}$ depth and from $9 \mathrm{~cm}$ to $5 \mathrm{~cm}$ at $30 \mathrm{~cm}$ depth. In the later period, the matrix potential of soil increased sharply, and on August 14, 2016, the matrix potential of soil was greater than that on August 6, 2016.

\subsubsection{Water Distribution in Covering Soil with a Thickness of $50 \mathrm{~cm}$}

(1) Transformation Law of Water Content. The change in soil water content in the test barrel with covering soil of $50 \mathrm{~cm}$ thickness is shown in Figure 6(a). During the test, the soil water content could be roughly divided into two sections: one was the soil water content at the depth of $30 \mathrm{~cm}$ and $50 \mathrm{~cm}$, and the other was at the depth of $10 \mathrm{~cm}, 70 \mathrm{~cm}$, and $90 \mathrm{~cm}$. The soil water content in the first section was greater than that in the second section. Under the influence of soil freezing in winter, there were some differences in different time periods. From August 6, 2016, to April 3, 2017, the soil water content in the first section was $0.30 \mathrm{~cm}^{3} \mathrm{~cm}^{-3}$ to $0.415 \mathrm{~cm}^{3} \mathrm{~cm}^{-3}$, and in the second section, the soil water content was $0.160 \mathrm{~cm}^{3} \mathrm{~cm}^{-3}$ to $0.261 \mathrm{~cm}^{3} \mathrm{~cm}^{-3}$. Affected by melting of the frozen soil layer, from April 3, 2017, to August 1,2017 , the soil water content in the first section decreased from $0.376 \mathrm{~cm}^{3} \mathrm{~cm}^{-3}$ to $0.236 \mathrm{~cm}^{3} \mathrm{~cm}^{-3}$, and the soil water content in the second section decreased from $0.215 \mathrm{~cm}^{3} \mathrm{~cm}^{-3}$ to $0.142 \mathrm{~cm}^{3} \mathrm{~cm}^{-3}$. The soil water content at the depth of $10 \mathrm{~cm}$ was still in the second section, which was caused by the influence of the surface micrometeorological conditions.

The change in soil water content after irrigation on August 7, 2016, is shown in Figure 6(b). Before irrigation, the water content was the lowest on August 6. After irrigation on August 7, 2016, the water infiltrated rapidly, and the soil water content reached the maximum at the depth of $30 \mathrm{~cm}$, which was $0.415 \mathrm{~cm}^{3} \mathrm{~cm}^{-3}$. On August 9, 2016, the water infiltrated to the depth of $50 \mathrm{~cm}$, that is, the interface between soil and block stone. Before the second irrigation, the soil water did not recover to the soil water of August 6, 2016, and the infiltration process was not completed.

(2) Transformation Law of Matrix Potential. During the observation period, the soil matrix potential values at depths of $10 \mathrm{~cm}, 30 \mathrm{~cm}$, and $50 \mathrm{~cm}$ ranged from $0.5 \mathrm{~cm}$ to $83 \mathrm{~cm}$, 


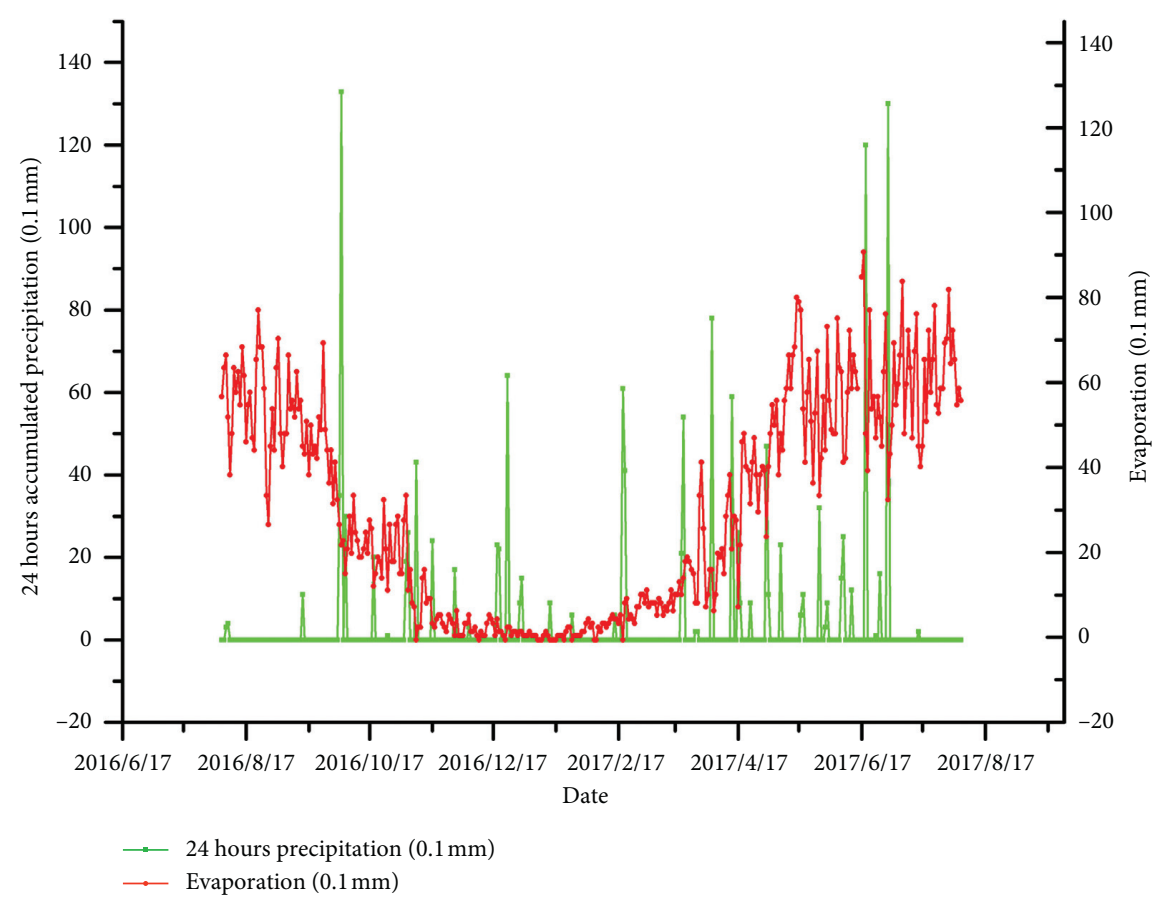

FIgURE 4: Statistical curves of precipitation and evaporation.

$3 \mathrm{~cm}$ to $73 \mathrm{~cm}$, and $5 \mathrm{~cm}$ to $76 \mathrm{~cm}$, respectively. Under the influence of meteorological factors, during the nonirrigation period, the surface soil was dry, and the value of matrix potential at the depth of $10 \mathrm{~cm}$ was greater than that of $30 \mathrm{~cm}$ and $50 \mathrm{~cm}$, which was consistent with the distribution of soil water content. At the same time, it could be seen that the impact of irrigation on matrix potential was greater than that of precipitation (Figure 6(c)).

It could be seen from Figure 6(d) that the matrix potential of soil decreased sharply after irrigation. The matrix potential at the depth of $10 \mathrm{~cm}$ decreased from $27.9 \mathrm{~cm}$ on August 6, 2016, to $3.7 \mathrm{~cm}$ on August 7, 2016, and then decreased to a minimum of $0.5 \mathrm{~cm}$ on August 9, 2016. At the depth of $30 \mathrm{~cm}$, the matrix potential decreased from $9.1 \mathrm{~cm}$ on August 6, 2016, to $5.6 \mathrm{~cm}$ on August 7, 2016, and to $3.0 \mathrm{~cm}$ on August 9, 2016. At the depth of $50 \mathrm{~cm}$, the matrix potential was $11.9 \mathrm{~cm}$ on August 6, 2016, decreased to $9.8 \mathrm{~cm}$ on August 7, 2016, and decreased to the lowest value of $7.5 \mathrm{~cm}$ on August 10, 2016. The matrix potential of each depth of soil began to increase gradually after it was reduced to the lowest, and on August 25, 2016, the matrix potential of $10 \mathrm{~cm}$ depth recovered to the value of August 6 , 2016.

\subsubsection{Water Distribution in Covering Soil with a Thickness of $70 \mathrm{~cm}$}

(1) Transformation Law of Water Content. The soil water content with a thickness of $70 \mathrm{~cm}$ is shown in Figure 7(a). During the test, the soil water content could be roughly divided into two sections: the first section was at the depth of $30 \mathrm{~cm}$ to $70 \mathrm{~cm}$, and the second section was at the depth of
$10 \mathrm{~cm}$ and $90 \mathrm{~cm}$. In general, the soil water content in the first section was greater than that in the second section. Under the influence of soil freezing in winter, there were some differences in different time periods. The soil water content at the depth of $10 \mathrm{~cm}$ was still low, which was caused by the influence of surface micrometeorological conditions.

It could be seen from Figure 7(b) that, on August 7, 2016, the soil water infiltrated rapidly. On August 9, 2016, the soil water infiltrated to the depth of $70 \mathrm{~cm}$ of the interface between soil and stone. Before the second irrigation, the soil water did not recover to the soil water content of August 6, 2016, and the infiltration process was not completed.

(2) Transformation Law of Matrix Potential. During the test, the matrix potential of soil with a thickness of $70 \mathrm{~cm}$ soil that changed with time is shown in Figure 7(c). During the observation period, the soil matrix potential at depths of $10 \mathrm{~cm}$, $30 \mathrm{~cm}, 50 \mathrm{~cm}$, and $70 \mathrm{~cm}$ ranged from $2.2 \mathrm{~cm}$ to $83 \mathrm{~cm}, 5.5 \mathrm{~cm}$ to $65 \mathrm{~cm}, 7.0 \mathrm{~cm}$ to $70 \mathrm{~cm}$, and $7.5 \mathrm{~cm}$ to $75 \mathrm{~cm}$. The matrix potential at the depth of $10 \mathrm{~cm}$ was most easily affected by surface meteorological factors such as irrigation and precipitation, and with the increase of depth, the degree of influence was reduced.

The change in soil matrix potential after one irrigation is shown in Figure 7(d). Before irrigation (August 6, 2016), the soil was dry and the matrix potential was large. After irrigation, the matrix potential of soil decreased sharply. On August 8, 2016, the matrix potential of soil reached the minimum. Then, the matrix potential began to increase gradually. On August 15, 2016, except for the depth of $10 \mathrm{~cm}$, which was greatly affected by weather, the matrix potential at other depths almost recovered to the state before irrigation. 


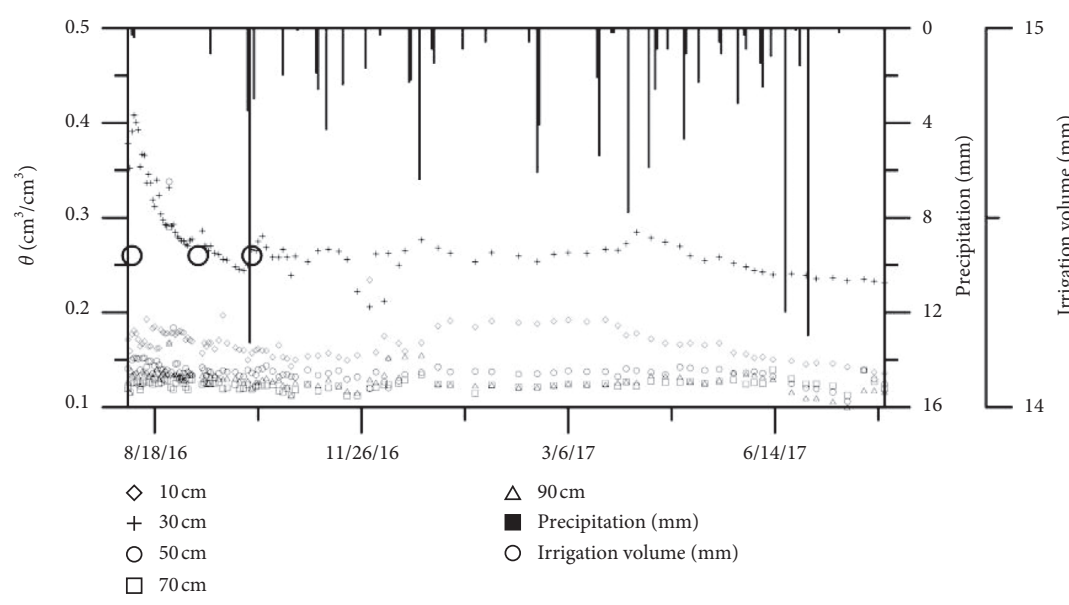

(a)

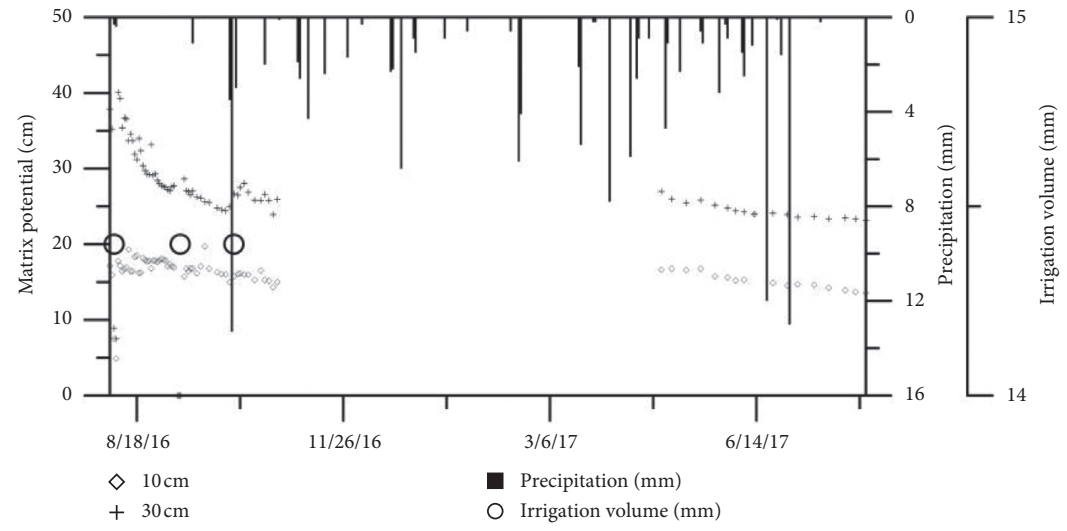

(c)

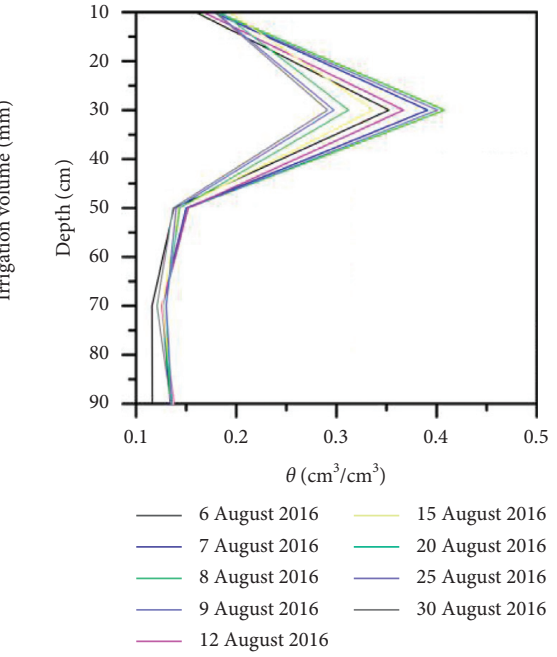

(b)

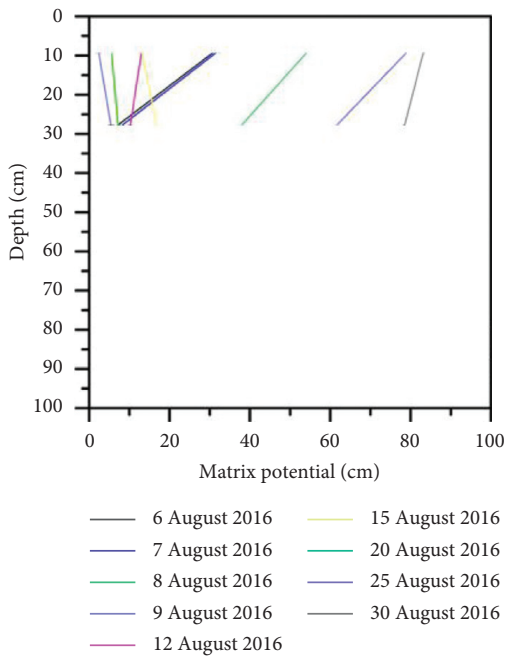

(d)

FIGURE 5: Water distribution in soil with a thickness of $30 \mathrm{~cm}$ with uncompaction: (a) water distribution at different depths; (b) response of water content to irrigation; (c) matrix potential at different depths; (d) response of matrix potential to irrigation.

\subsection{Water Distribution in Once-Compacted Soil}

\subsubsection{Water Distribution in Covering Soil with a Thickness of $30 \mathrm{~cm}$}

(1) Transformation Law of Water Content. During the test, the change in soil water content of covering soil with compaction once of $30 \mathrm{~cm}$ thickness is shown in Figure 8(a). It could be seen from this figure that there were obvious differences in soil water content at $10 \mathrm{~cm}$ and $30 \mathrm{~cm}$ depths. The soil water content at the depth of $10 \mathrm{~cm}$ was from $0.15 \mathrm{~cm}^{3} \mathrm{~cm}^{-3}$ to $0.20 \mathrm{~cm}^{3} \mathrm{~cm}^{-3}$, while the soil water content at the depth of $30 \mathrm{~cm}$ was from $0.22 \mathrm{~cm}^{3} \mathrm{~cm}^{-3}$ to $0.26 \mathrm{~cm}^{3}$ $\mathrm{cm}^{-3}$. In the waste rock of the lower layer of covering soil, the water content was from $0.10 \mathrm{~cm}^{3} / \mathrm{cm}^{3}$ to $0.14 \mathrm{~cm}^{3} / \mathrm{cm}^{3}$, which was lower than that of the upper layer.

The change in soil water content after one irrigation is shown in Figure 8(b). After irrigation on August 7, 2016, the soil water content at the depth of $10 \mathrm{~cm}$ reached a maximum of $0.189 \mathrm{~cm}^{3} \mathrm{~cm}^{-3}$ on August 12, 2016. With the infiltration, the soil water content at the depth of $30 \mathrm{~cm}$ was basically the same as that on August 6, 2016, which indicated that the infiltration process of one irrigation was basically completed and lasted for 18 days.

(2) Transformation Law of Matrix Potential. The matrix potential change of reconstructed soil with a thickness of $30 \mathrm{~cm}$ and compaction once is shown in Figure 8(c). During the test, the matrix potential at the depth of $10 \mathrm{~cm}$ and $30 \mathrm{~cm}$ was from $12 \mathrm{~cm}$ to $82 \mathrm{~cm}$ and from $8 \mathrm{~cm}$ to $78 \mathrm{~cm}$, respectively. At the same time, it could be seen that the matrix potential was very sensitive to irrigation. After irrigation, the matrix potential decreased sharply.

The matrix potential change in reconstructed soil after irrigation is shown in Figure 8(d). It could be seen from this figure that, after irrigation, the matrix potential of soil at the depth of $10 \mathrm{~cm}$ decreased sharply, to a minimum of $12 \mathrm{~cm}$ on August 9, 2016. On August 15, 2016, the matrix potential at 


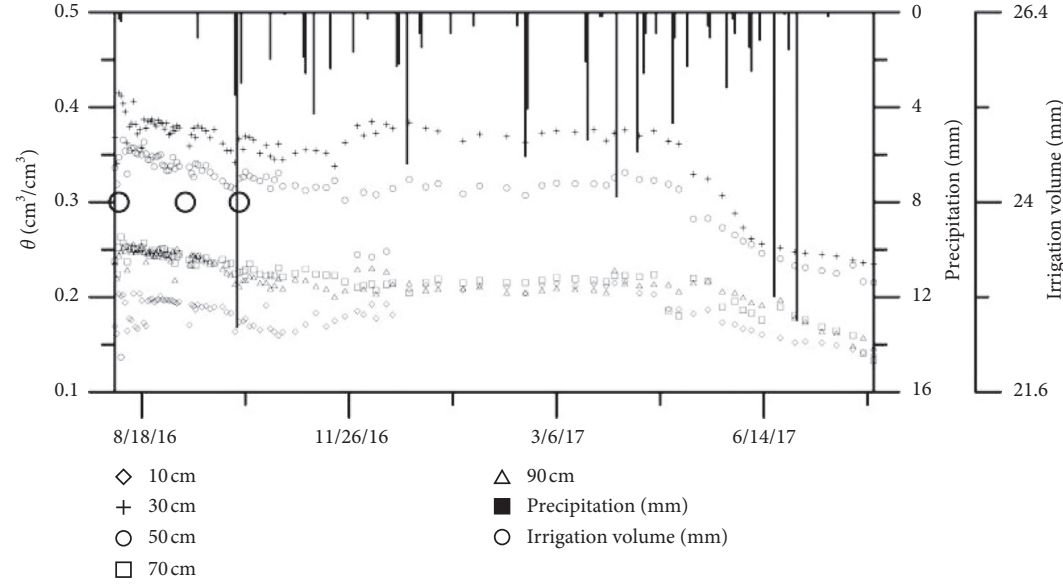

(a)

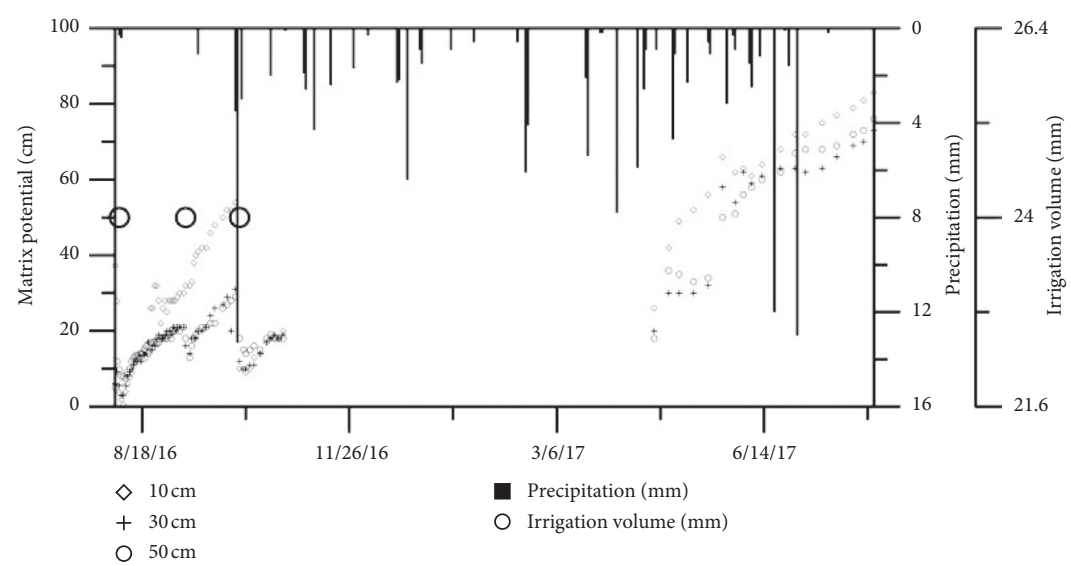

(c)

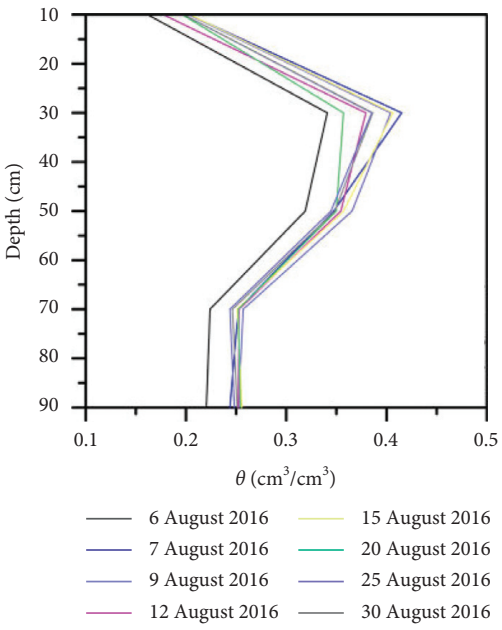

(b)

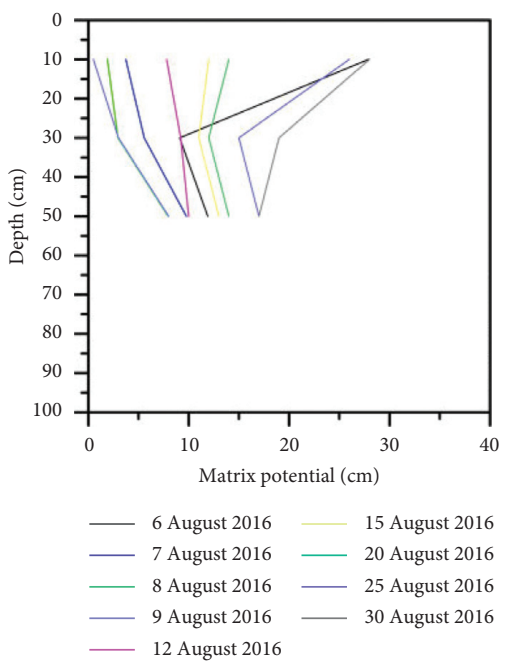

(d)

FIGURE 6: Water distribution in soil with a thickness of $50 \mathrm{~cm}$ with uncompaction: (a) water distribution at different depths; (b) response of water content to irrigation; (c) matrix potential at different depths; (d) response of matrix potential to irrigation.

the depth of $10 \mathrm{~cm}$ returned to the level of August 6, 2016, before irrigation.

\subsubsection{Water Distribution in Covering Soil with a Thickness of $50 \mathrm{~cm}$}

(1) Transformation Law of Water Content. The change in soil water content of covering soil with compaction once of $50 \mathrm{~cm}$ thickness is shown in Figure 9(a). During the test, the soil water content of $50 \mathrm{~cm}$ thick covering soil could be roughly divided into two sections. The soil water content was from $0.25 \mathrm{~cm}^{3} \mathrm{~cm}^{-3}$ to $0.325 \mathrm{~cm}^{3} / \mathrm{cm}^{3}$ at the depth of $30 \mathrm{~cm}$ and from $0.1 \mathrm{~cm}^{3} \mathrm{~cm}^{-3}$ to $0.175 \mathrm{~cm}^{3} \mathrm{~cm}^{-3}$ at the depth of $10 \mathrm{~cm}$ and $50 \mathrm{~cm}-90 \mathrm{~cm}$.

The response of water content in covering soil with a thickness of $50 \mathrm{~cm}$ and compaction once to irrigation is shown in Figure 9(b). After irrigation on August 7, 2016, the water of soil at the depth of $10 \mathrm{~cm}$ quickly infiltrated. On
August 15, 2016, the soil water content at the depth of $30 \mathrm{~cm}$ reached the maximum value of $0.282 \mathrm{~cm}^{3} \mathrm{~cm}^{-3}$. On August 22,2016 , the soil water content at the depth of $50 \mathrm{~cm}$ reached the maximum value of $0.26 \mathrm{~cm}^{3} \mathrm{~cm}^{-3}$.

(2) Transformation Law of Matrix Potential. The matrix potential change in reconstructed soil with a thickness of $50 \mathrm{~cm}$ and compaction once is shown in Figure 9(c). During the test, the matrix potential at the depth of $10 \mathrm{~cm}, 30 \mathrm{~cm}$, and $50 \mathrm{~cm}$ was from $8 \mathrm{~cm}$ to $72 \mathrm{~cm}, 17.2 \mathrm{~cm}$ to $76.2 \mathrm{~cm}$, and $42 \mathrm{~cm}$ to $84 \mathrm{~cm}$, respectively. Matrix potential at the depth of $10 \mathrm{~cm}$ and $30 \mathrm{~cm}$ was sensitive to the change in irrigation. After irrigation, the matrix potential decreased rapidly from about $70 \mathrm{~cm}$ to about $10 \mathrm{~cm}$ in a very short time.

The matrix potential change in reconstructed soil with a thickness of $50 \mathrm{~cm}$ and compaction once after irrigation is shown in Figure 9(d). After irrigation on August 7, 2016, the matrix potential at the depth of $10 \mathrm{~cm}$ decreased rapidly. On August 9, 2016, the matrix potential reached the minimum 


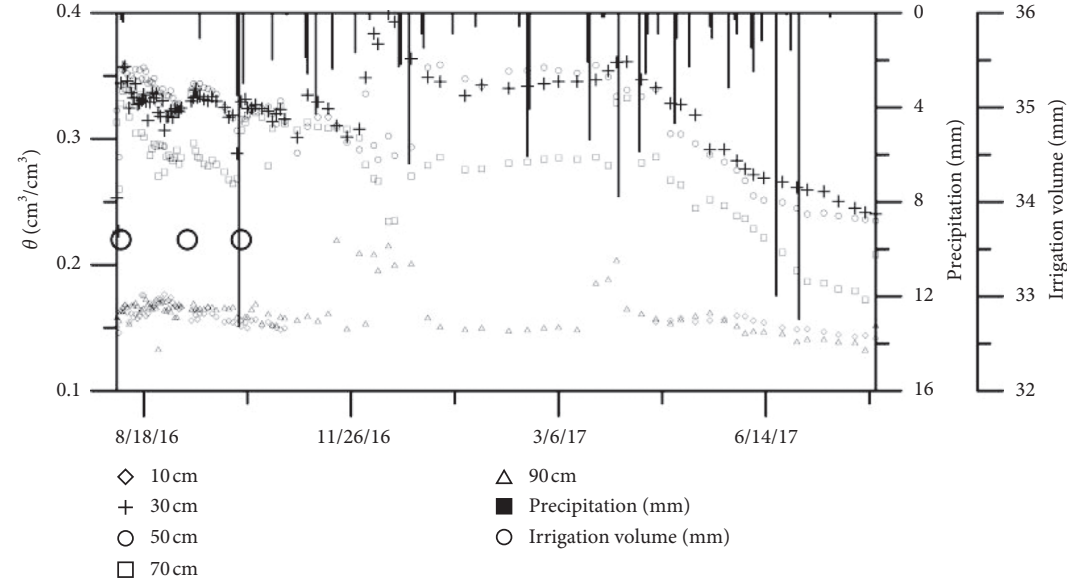

(a)

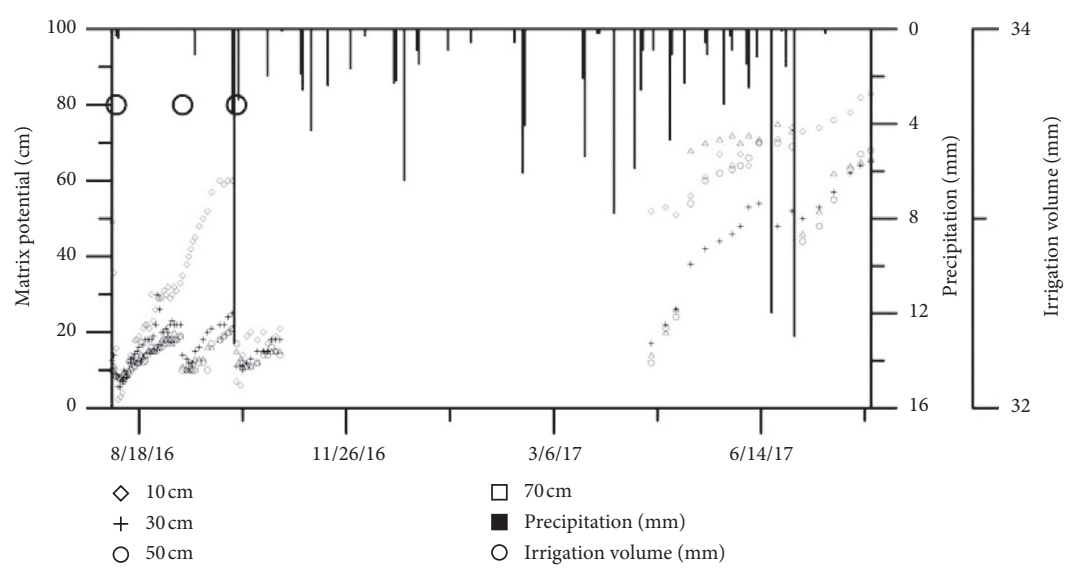

(c)

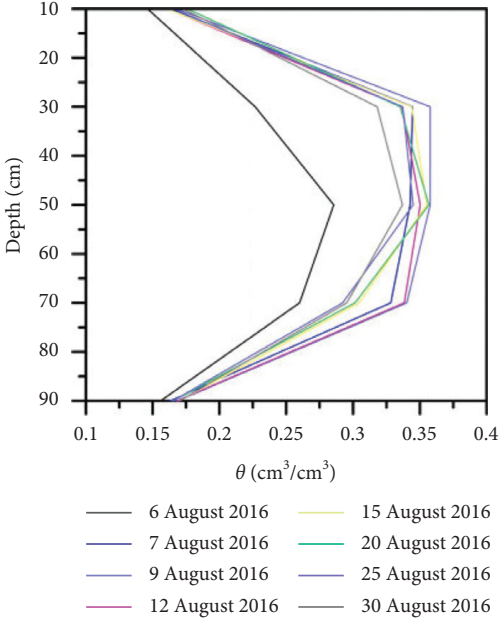

(b)

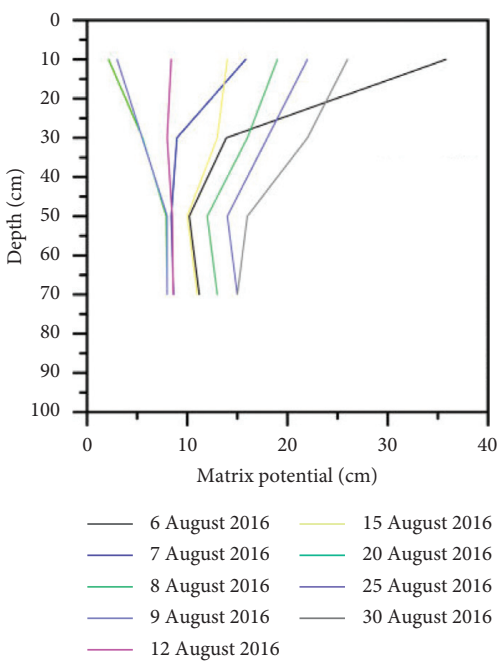

(d)

FIGURE 7: Water distribution in soil with a thickness of $70 \mathrm{~cm}$ with uncompaction: (a) water distribution at different depths; (b) response of water content to irrigation; (c) matrix potential at different depths; (d) response of matrix potential to irrigation.

value of $8.2 \mathrm{~cm}$. On August 15, 2016, the matrix potential at the depth of $30 \mathrm{~cm}$ reached the minimum value of $18.1 \mathrm{~cm}$. On the interface between the soil and the mining waste rock (the depth is $50 \mathrm{~cm}$ ), the matrix potential changed little.

\subsubsection{Water Distribution in Covering Soil with a Thickness of $70 \mathrm{~cm}$}

(1) Transformation Law of Water Content. The change in soil water content of covering soil with compaction once of $70 \mathrm{~cm}$ thickness is shown in Figure 10(a). The soil water content of $70 \mathrm{~cm}$ thick covering soil could be roughly divided into two sections. In general, the soil water content was from $0.125 \mathrm{~cm}^{3} \mathrm{~cm}^{-3}$ to $0.175 \mathrm{~cm}^{3} \mathrm{~cm}^{-3}$ at the depth of $10 \mathrm{~cm}$ and $90 \mathrm{~cm}$ and from $0.175 \mathrm{~cm}^{3} \mathrm{~cm}^{-3}$ to $0.3 \mathrm{~cm}^{3} \mathrm{~cm}^{-3}$ at the depth of $30 \mathrm{~cm}, 50 \mathrm{~cm}$, and $70 \mathrm{~cm}$. The reason for the lower soil water content at the depth of $10 \mathrm{~cm}$ is that the surface soil is greatly affected by micrometeorological, and the lower soil water content at the depth of $90 \mathrm{~cm}$ is that this depth is waste rock.

The response of water content in covering soil with a thickness of $50 \mathrm{~cm}$ and compaction once to irrigation is shown in Figure 10(b). After irrigation on August 7, 2016, the soil water infiltrated rapidly. On August 8, 2016, the soil water content at the depth of $30 \mathrm{~cm}$ reached the maximum value of $0.345 \mathrm{~cm}^{3} \mathrm{~cm}^{-3}$. On August 12, 2016, the soil water content at the depth of $50 \mathrm{~cm}$ reached the maximum value of $0.241 \mathrm{~cm}^{3} \mathrm{~cm}^{-3}$. On August 20, 2016, the soil water content at the depth of $70 \mathrm{~cm}$ reached the maximum value of $0.199 \mathrm{~cm}^{3} \mathrm{~cm}^{-3}$. As time goes on, soil water did not recover to the value of soil water on August 6 before the second irrigation.

(2) Transformation Law of Matrix Potential. The matrix potential change in reconstructed soil with a thickness of $70 \mathrm{~cm}$ and compaction once is shown in Figure 10(c). During the test, the matrix potential values at the depth of 


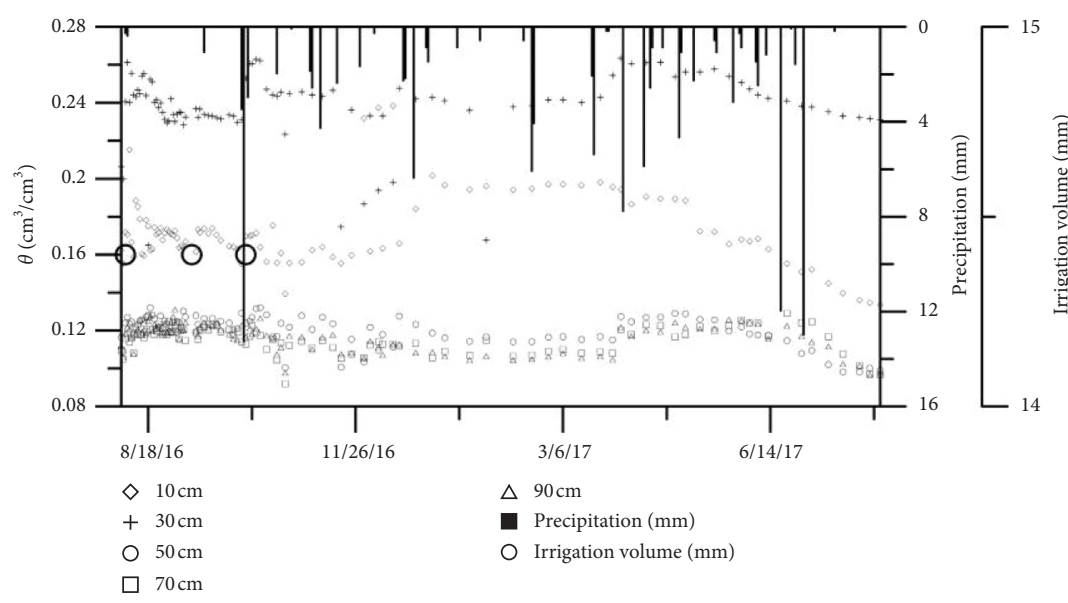

(a)

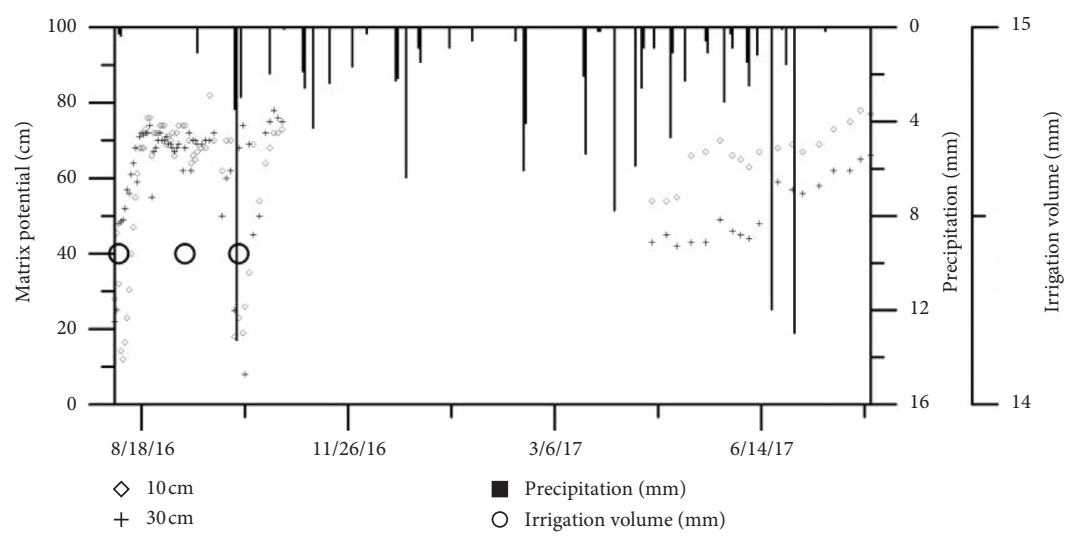

(c)

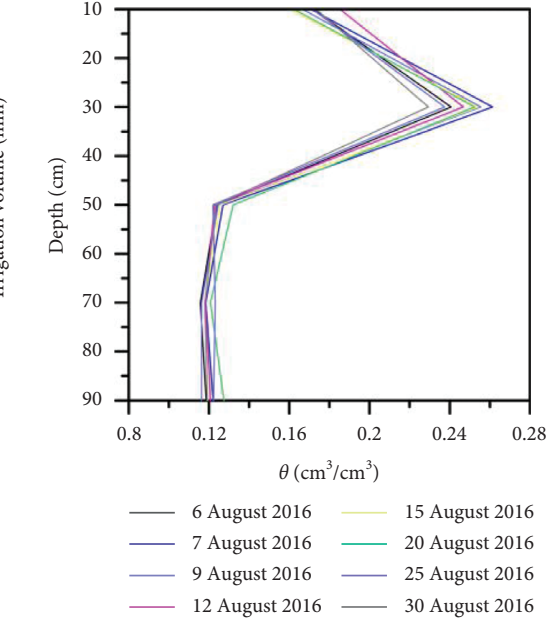

(b)

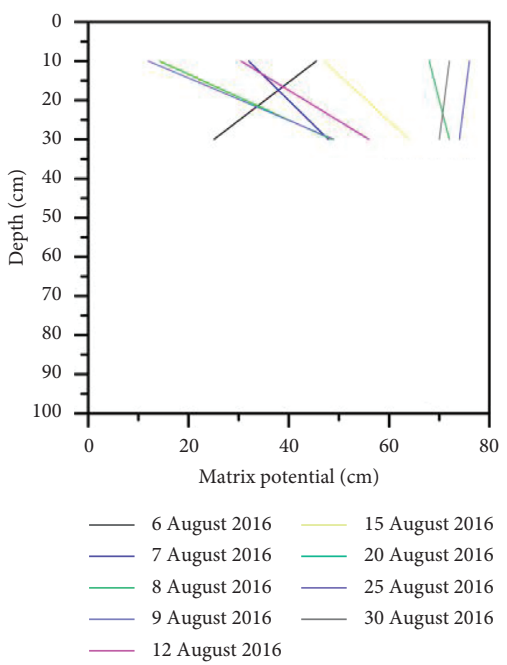

(d)

FIGURE 8: Water distribution in soil with a thickness of $30 \mathrm{~cm}$ with compaction once: (a) water distribution at different depths; (b) response of water content to irrigation; (c) matrix potential at different depths; (d) response of matrix potential to irrigation.

$10 \mathrm{~cm}, 30 \mathrm{~cm}, 50 \mathrm{~cm}$, and $70 \mathrm{~cm}$ were from $8.2 \mathrm{~cm}$ to $82 \mathrm{~cm}$, $7.8 \mathrm{~cm}$ to $54 \mathrm{~cm}, 10.2 \mathrm{~cm}$ to $78 \mathrm{~cm}$, and $11 \mathrm{~cm}$ to $80 \mathrm{~cm}$, respectively. Matrix potential values at the depth of $10 \mathrm{~cm}$, $30 \mathrm{~cm}$, and $50 \mathrm{~cm}$ were sensitive to irrigation. At the depth of $70 \mathrm{~cm}$ of the interface of soil and mining waste rock, the response of matrix potential to irrigation was weak.

The matrix potential change in reconstructed soil with a thickness of $70 \mathrm{~cm}$ and compaction once after irrigation is shown in Figure 10(d). After irrigation, the matrix potential of the surface soil decreased rapidly. On August 9, 2016, the matrix potential at the depth of $10 \mathrm{~cm}, 30 \mathrm{~cm}$, and $50 \mathrm{~cm}$ was reduced to the minimum.

3.3. Comparative Analysis and Ecological Effects of Reconstructed Soil Water Distribution. As shown in Figure 11, the water content of the reconstructed soil with different thicknesses at different depths and for different reclamation methods is compared. The water content was the lowest at a depth of $10 \mathrm{~cm}$. This low water content occurred because the reconstructed soil on the surface was easily affected by climate and was characterized by strong evaporation. The water content was generally higher at a depth of $30 \mathrm{~cm}$. The physical properties of the reconstructed soil at the early stage [24] show that the fine particle content at this depth was generally lower than that of the other soil depths, and the porosity was generally large [25], which provided space for the storage of water.

In Xinjiang, alfalfa, Cape grass, Artemisia, and other vegetation are generally selected for land reclamation of nonmetal mines. The root length of these plants varies with the growth stage of vegetation. The root length is approximately $10 \mathrm{~cm}$ in the early growth stage, $50 \mathrm{~cm}$ [26-28] at 6 months, and more than $1 \mathrm{~m}$ after $3-4$ years. It could be seen from Figure 11 that there was little difference in water content at a depth of $10 \mathrm{~cm}$ in the early stages of plant growth, and the highest water content was in the test barrel with a soil thickness of $50 \mathrm{~cm}$ with noncompacted soil. To 


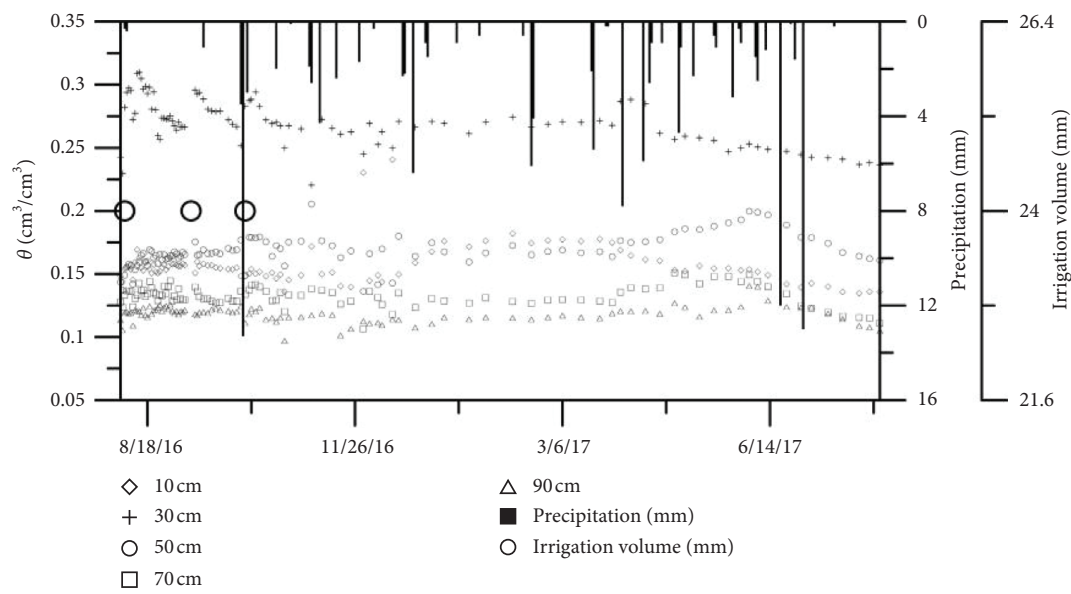

(a)

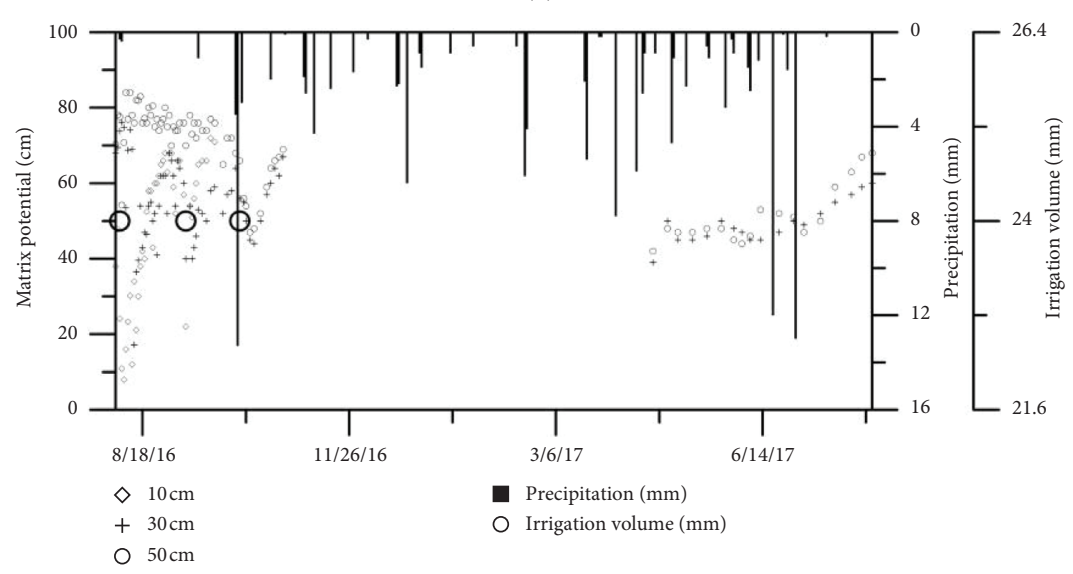

(c)

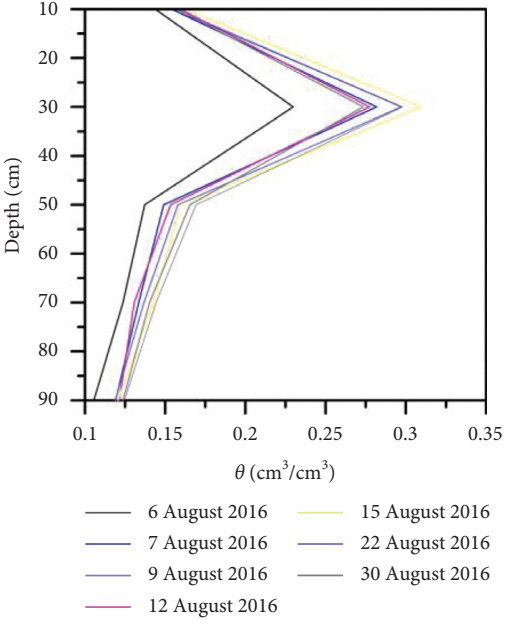

(b)

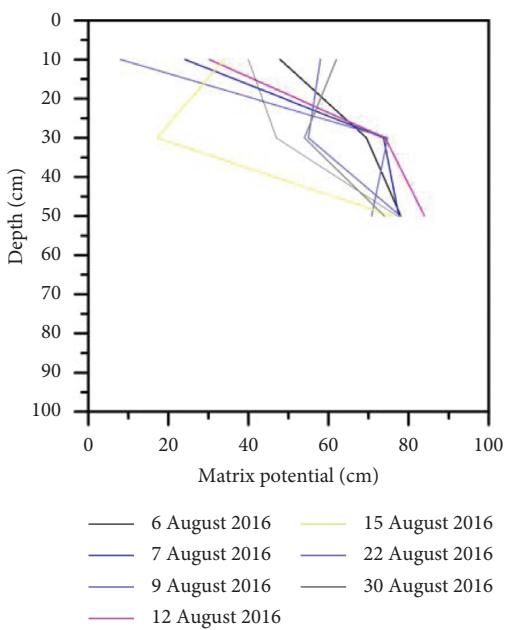

(d)

Figure 9: Water distribution in soil with a thickness of $50 \mathrm{~cm}$ with compaction once: (a) water distribution at different depths; (b) response of water content to irrigation; (c) matrix potential at different depths; (d) response of matrix potential to irrigation.

compare the average water content of $50 \mathrm{~cm}$ thick soil (after 6 months of plant root growth) of barrels, the average water content of $50 \mathrm{~cm}$ thick soil of the barrels was made into curves (Figure 12). It could be seen from this figure that the barrels with $30 \mathrm{~cm}$ of soil had the lowest average soil water content at the half-year growth point of the plants, and the noncompacted barrels with $50 \mathrm{~cm}$ and $70 \mathrm{~cm}$ of reconstructed soil had the highest average soil water content for the same time period. This suggests that the soil thickness should not be less than $50 \mathrm{~cm}$. As the plants grow, their roots can reach $1 \mathrm{~m}$. Since the test was only conducted for one year, it could be inferred from the change in water content (Figure 13) that the water content of noncompacted reconstructed soil decreased greatly over time. The water content of the uncompacted soil was similar to or lower than that of the compacted reconstructed soil, which suggests that once-compacted soil was beneficial to plant growth over the long term.

\section{Mechanism of Water Distribution in Reconstructed Soil}

From the analysis of a large number of data obtained in this test, whether the upper soil is compacted or not, the water content of the upper soil is greater than that of the lower waste rock. The principle of the influence of the double-layer structure with fine upper soil particles and coarse lower soil particles on the water holding capacity can be obtained from the analysis of Young's Laplace equation.

It is assumed that there is a capillary with a radius of $r$, and there is a small water drop in this capillary. Now, the equilibrium of the force on the water drop is studied (Figure 14):

$$
P_{1}=P_{2}+M
$$




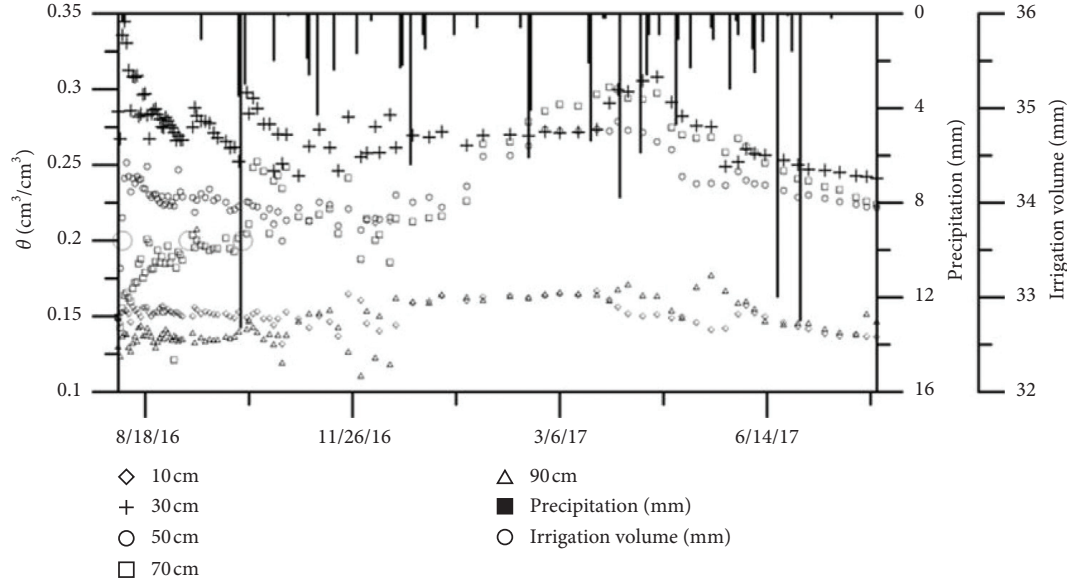

(a)

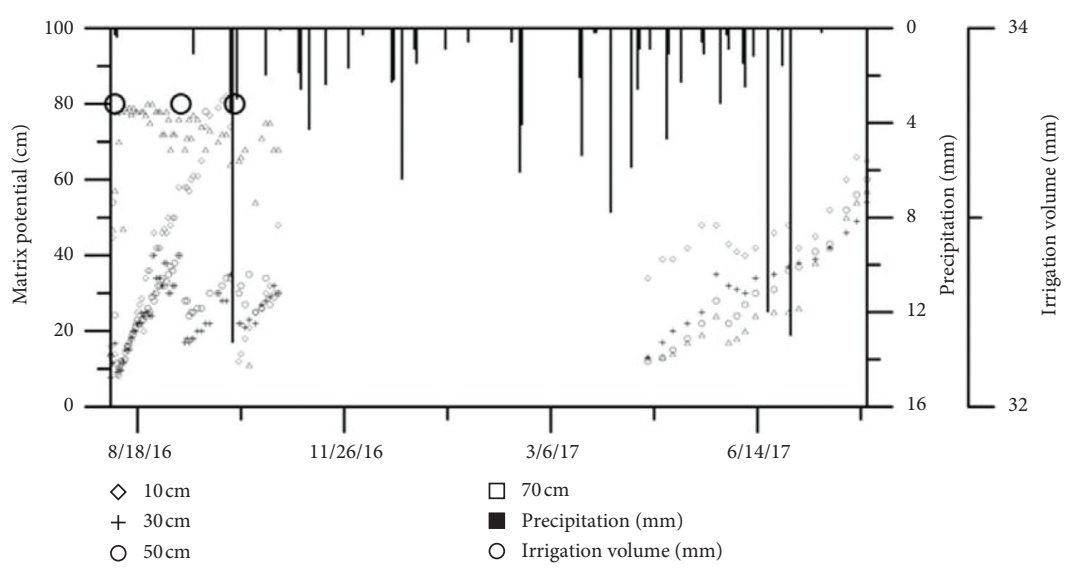

(c)

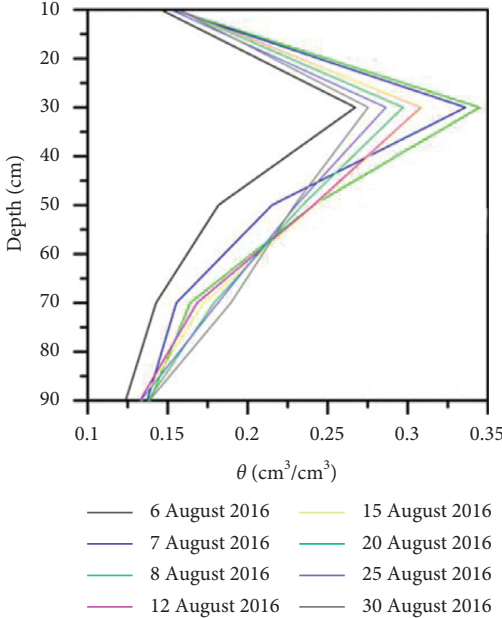

(b)

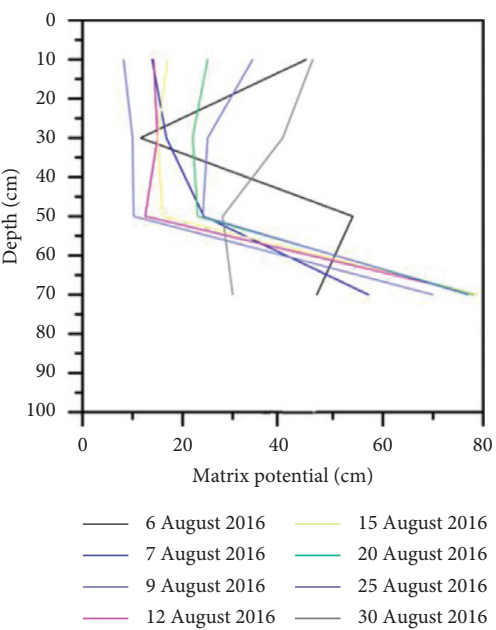

(d)

FIgURE 10: Water distribution in soil with a thickness of $70 \mathrm{~cm}$ with compaction once: (a) water distribution at different depths; (b) response of water content to irrigation; (c) matrix potential at different depths; (d) response of matrix potential to irrigation.

In formula (1), $P_{1}$ and $P_{2}$ are the pressure added to the liquid by the concave surface and $M$ is the gravity of the water drop.

Applying Laplace equation, we get the following formula:

$$
\alpha \frac{2}{R_{1}}=\rho g h+\alpha \frac{2}{R_{2}}
$$

After transforming formula (2), we could get the following formula:

$$
\rho g h=2 \alpha\left(\frac{1}{R_{1}}-\frac{1}{R_{2}}\right)
$$

Because of $\rho g h>0$, the stable condition of water droplet in capillary must be $1 / R_{1}>1 / R_{2}$, that is, the radius of curvature of the upper meniscus is smaller than that of the lower meniscus. This is the reason why the water content of finegrained soil in the upper layer is higher than that of coarsegrained soil in the lower layer.

\section{Discussion}

The physical and hydraulic parameters of filled and reconstructed soil are quite different from those of natural soil. In this paper, the water distribution of surface covering soil of nonmetallic and metal mines was studied. The reconstructed soil profile study is different from previous studies. In the past, the researches on the properties and water distribution of the reconstructed soil were mostly concentrated in the coal mines area $[4,5,15-18,22,23]$. The lower part of the reconstructed soil profile was composed of coal gangue or fly ash, and the upper part was covered by the original soil of the coal mines. The physical properties and hydraulic parameters of the filler (gangue or fly ash) are quite different from the bulk waste rock produced by the mining of metal and nonmetal ores. The surface covering soil was the most widely distributed brown calcium soil in Xinjiang, which belongs to sandy soil. Its physical and hydraulic parameters are different from those in other regions $[4,10,12,22]$. Reconstructed soil profile 


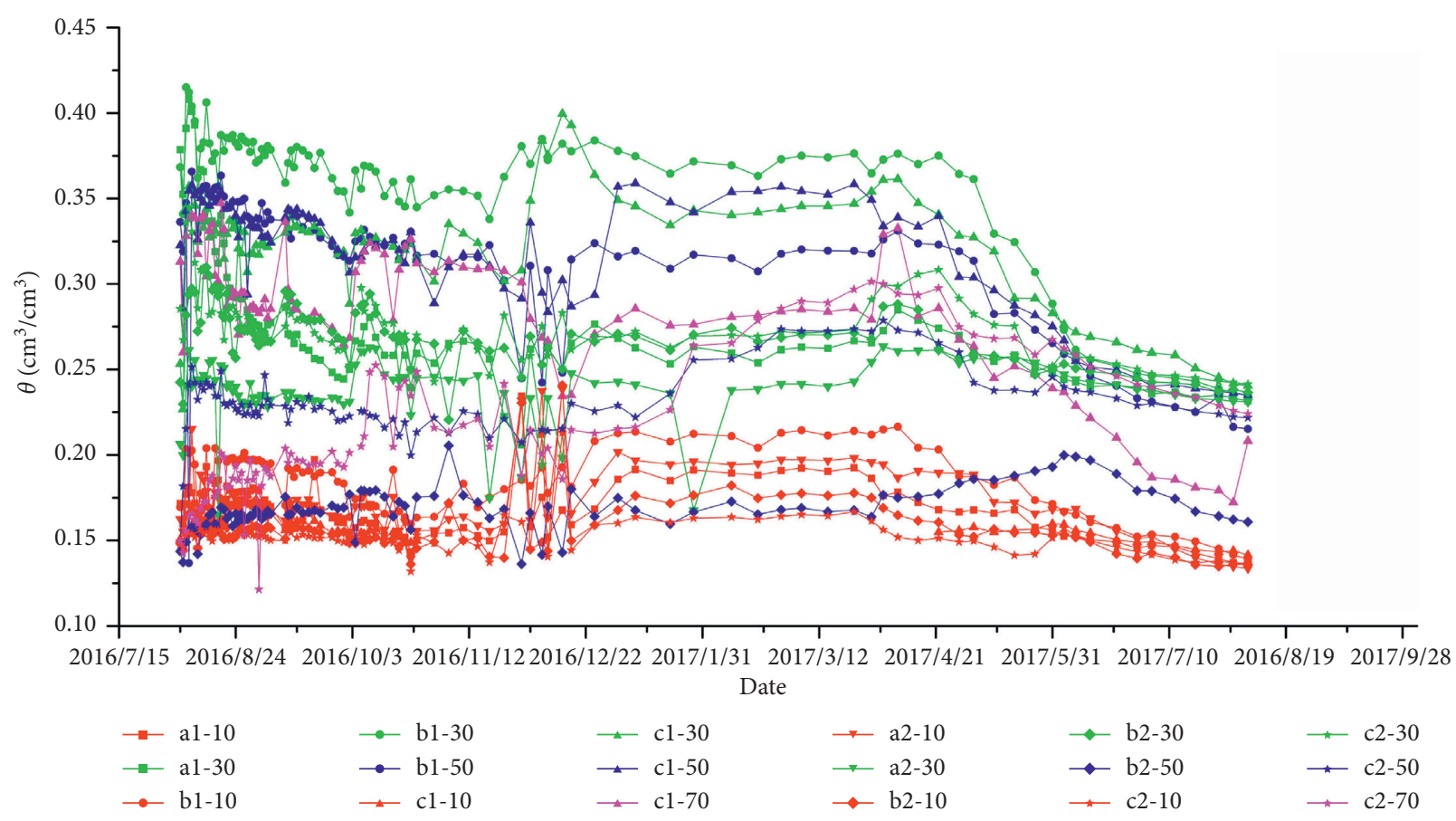

Figure 11: Curves of soil water content varying with time in reconstructed soil at different depths.

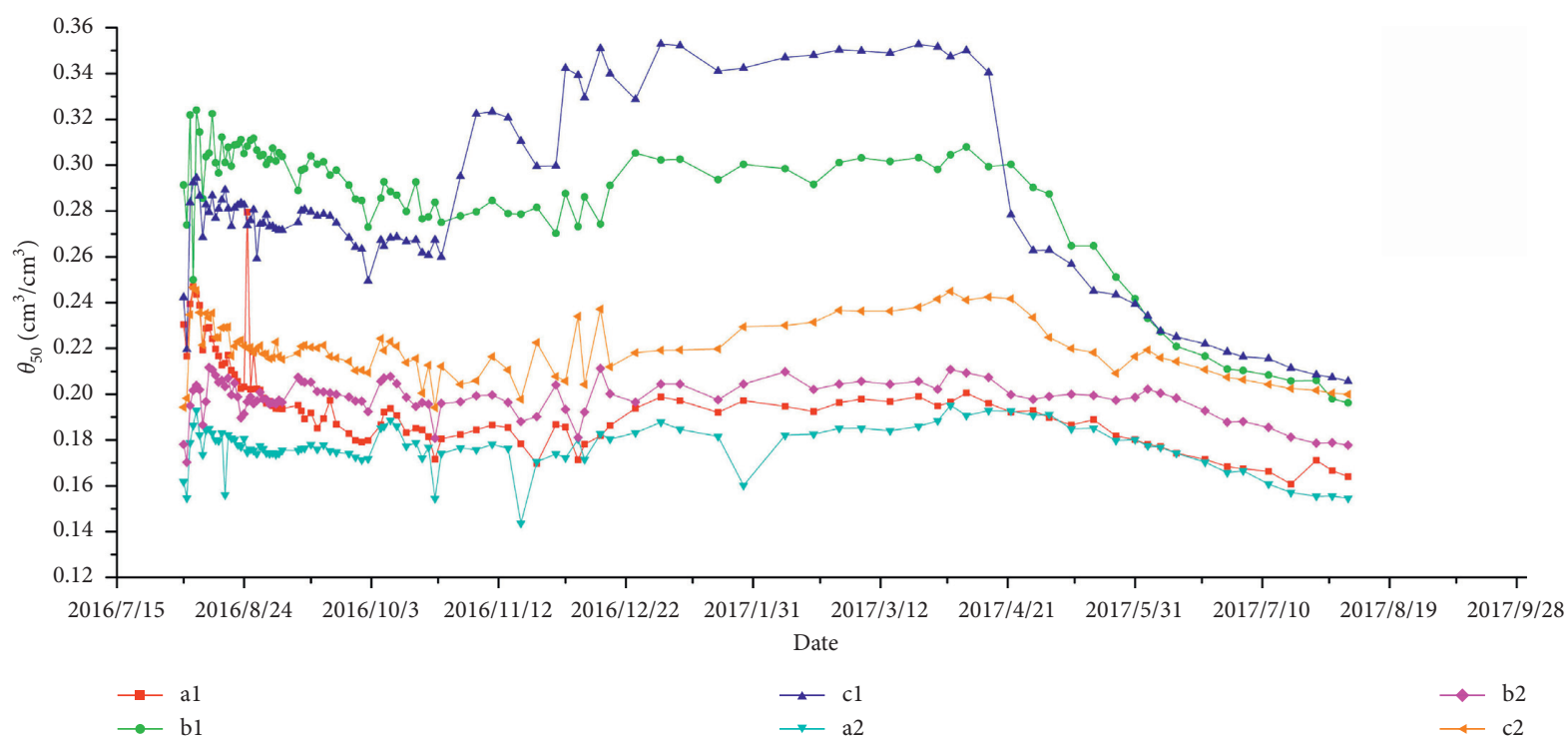

FIgURE 12: Curves of the average water content of $50 \mathrm{~cm}$ thick soil varying with time.

composition of this research has pertinence and uniqueness.

The experimental methods of simulating soil water distribution mainly include indoor soil column experiment $[4,5]$ and field experiment $[8,9]$. The reconstructed soil was covered with the thickness and compaction conditions commonly used in Xinjiang. Irrigation volume and frequency were also carried out using the irrigation standard of artificial grassland in this area. This in situ test is in line with the actual situation of soil reconstruction of mine land reclamation in Xinjiang. The methods of analyzing soil water include sampling for laboratory experiments [22], ground- penetrating radar [3], and cosmic ray probe analysis [12]. In this research, the neutron probe observation method, which had been used for many years in this test site, was used to analyze the water content of reconstructed soil at different depths, and the test results were accurate.

The biggest deficiency of this field in situ test is that it does not combine vegetation growth to study the change in water content of reconstructed soil. This study was only focused on the characteristics of reconstructed soil water distribution under irrigation conditions in the arid and cold areas of Xinjiang. In the later stage, on the basis of this research results, we will plant alfalfa in the test site and 


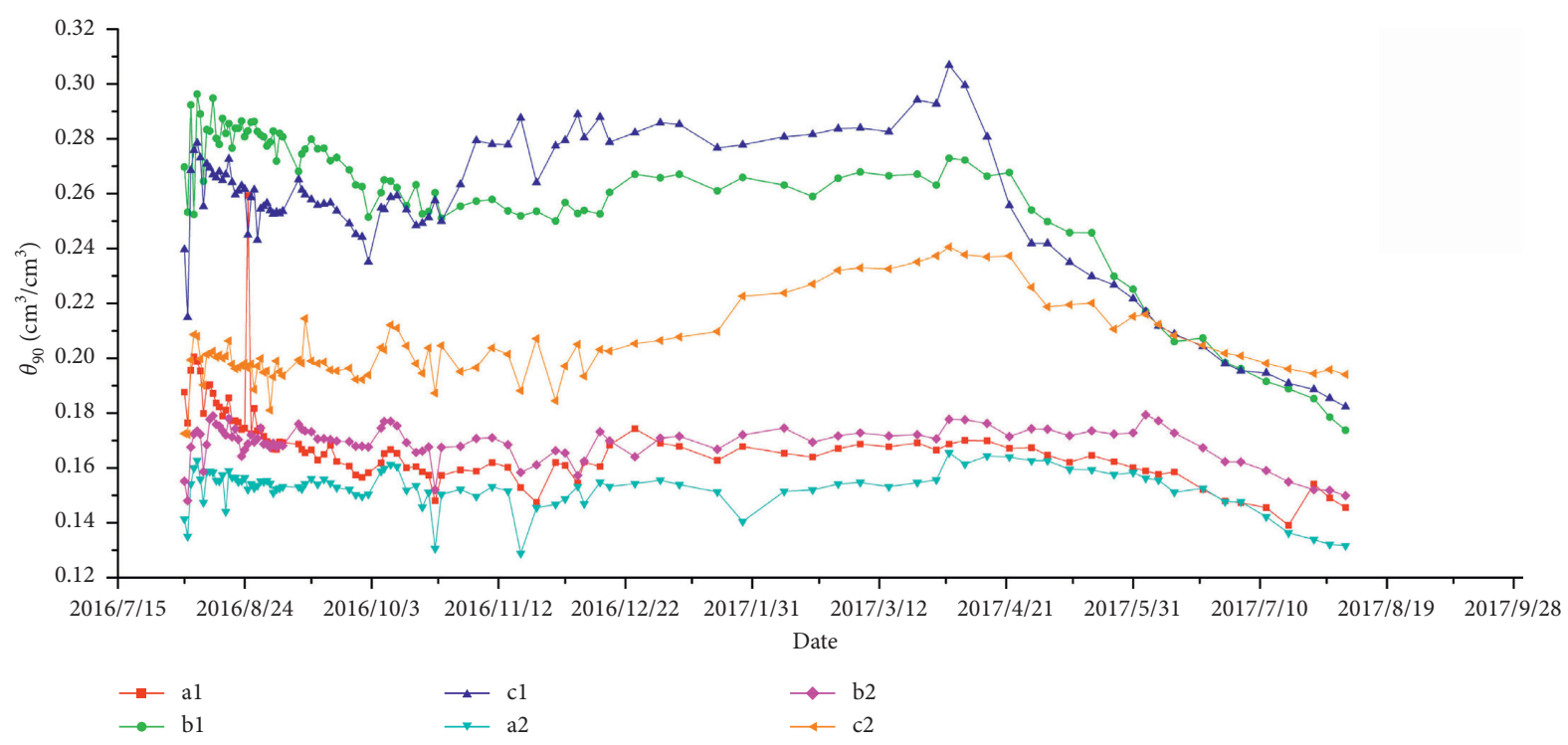

FIgURE 13: Curves of the average water content of $90 \mathrm{~cm}$ thick soil varying with time.

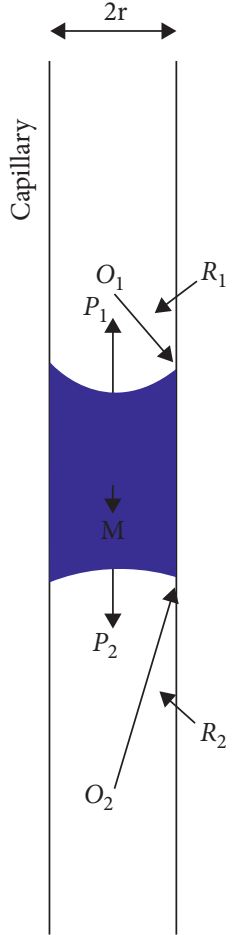

FIGURE 14: Diagram of soil water holding capacity.

combine the plant growth to study the law of reconstructed soil water distribution.

\section{Conclusions}

In this paper, the law of water distribution of reconstructed soil with different thicknesses under the action of uncompaction and compaction once in a year's management and protection period was obtained. Whether the soil is compacted or uncompacted, the water content at the depth of $10 \mathrm{~cm}$ is less than that at other depths of the reconstructed soil due to the influence of meteorological factors. The water content of reconstructed soil at $30 \mathrm{~cm}$ depth is higher than that at other depths due to its highest porosity. The response time of soil water content and matrix potential to irrigation infiltration is different under the influence of soil thickness and compaction. For the covering soil with a thickness of $30 \mathrm{~cm}$, the effect of compaction on soil water content is small. For the covering soil with a thickness of $50 \mathrm{~cm}$ and $70 \mathrm{~cm}$, the water content of compacted soil is lower than that of uncompacted soil due to the decrease in porosity. Considering the water demand of vegetation growth in the process of land reclamation, the thickness of reconstructed soil should not be less than $50 \mathrm{~cm}$. Considering the longterm growth of vegetation, the reconstructed soil with compaction once is more conducive to plant growth. For the covering soil with a thickness of $30 \mathrm{~cm}$, the effect of compaction on soil water content is small. In future research, we will combine the plant growth to study the reconstructed soil water distribution.

\section{Data Availability}

The data used to support the findings of this study are included within the article.

\section{Conflicts of Interest}

The authors declare that there are no conflicts of interest.

\section{Authors' Contributions}

Z. Z. and X. G. conceived the main idea of the paper and designed the test scheme. Q. L., R. H., Z. G., X. H., and Z. G. performed the test scheme and analyzed the data. Z. Z. wrote the paper. X. G. worked to modify figures and proofread the revised version. 


\section{Acknowledgments}

This research was funded by the Natural Science Foundation of Xinjiang (Grant no. 2018D01C061).

\section{References}

[1] X. Jiao, L. Wang, C. Lu, C. Gao, E. Dong, and X. Liu, "Effects of two reclamation methodlogies fo coal ming subsidence on soil physical and chemical properties," Journal of Soil and Water Conservation, vol. 23, no. 4, pp. 123-125+145, 2009.

[2] S. Mu, W. Dong, H. Wang, H. Zhao, and Z. Bian, "Study of reclaimed soil respiration on the site by filling mining wastes and fly ash into subsidence area due to coal ming," Journal of China University of Mining and Technology, vol. 5, pp. 663668, 2007.

[3] Z. Hu, B. Chen, S. Wang, and X. Chen, "Using ground penetrating radar to measure water content of rehabilitated soil," Journal of Hebei Institute of Architectural Science and Technology, vol. 22, no. 1, pp. 1-3, 2005.

[4] J. Wang, X. Li, Z. Bai, and L. Huang, "The effects of coal gangue and fly ash on the hydraulic properties and water content distribution in reconstructed soil profiles of coalmined land with a high groundwater table," Hydrological Processes, vol. 31, no. 3, pp. 687-697, 2017.

[5] Y. Song, J. Wang, X. Li, K. Wu, and Z. Bai, "Simulation of moisture transfer law with different soil reconstruction models in coal mining subsided area with high ground-water level," Journal of Soil and Water Conservation, vol. 30, no. 2, pp. 143-148+154, 2016.

[6] Z. Hu and X. Zhang, "Artificial neural network for predicting water retention curves of reclaimed soil," Transactions of the CSAE, vol. 10, pp. 15-19, 2008.

[7] J. Wei, X. He, C. Hu, and J. Wang, "Influence of ground collapse caused by coal mining activities on the water characteristics of sandy soil in arid and semi-arid area," Journal of Arid Land Resources and Environment, vol. 5, pp. 84-88, 2006.

[8] M. Bordoni, M. Bittelli, R. Valentino, S. Chersich, and C. Meisina, "Improving the estimation of complete field soil water characteristic curves through field monitoring data," Journal of Hydrology, vol. 552, pp. 283-305, 2017.

[9] F. Shao, P. Wang, Z. Hu, J. Zeng, Y. Chen, and E. Li, "Vertical infiltration characteristics of reclamation farmland soil filled with the yellow river sediment," Journal of Soil and Water Conservation, vol. 27, no. 5, pp. 54-58+67, 2013.

[10] Y. Yu, S. Ren, L. Guo, and B. B, "Study on soil water-holding capacity between two types of reclamation agroforestry land on a coal waste pile," Research of Soil and Water Conservation, vol. 23, no. 2, pp. 44-48, 2016.

[11] J. J. Carrera-Hernández, C. A. Mendoza, K. J. Devito, R. M. Petrone, and B. D. Smerdon, "Reclamation for aspen revegetation in the Athabasca oil sands: understanding soil water dynamics through unsaturated flow modelling," $\mathrm{Ca}$ nadian Journal of Soil Science, vol. 92, no. 1, pp. 103-116, 2012.

[12] M. J. P. Sigouin, M. Dyck, B. C. Si, and W. Hu, "Monitoring soil water content at a heterogeneous oil sand reclamation site using a cosmic-ray soil moisture probe," Journal of Hydrology, vol. 543, pp. 510-522, 2016.

[13] Z.-S. Li and L.-S. Tang, "Using synchrotron-based X-ray microcomputed tomography to characterize water distribution in compacted soils," Advances in Materials Science and Engineering, vol. 2019, Article ID 7147283, 11 pages, 2019.
[14] R. Davies, A. Younger, and R. Chapman, "Water availability in a restored soil," Soil Use \& Management, vol. 8, pp. 67-73, 1992.

[15] D. Gupta, U. Rai, R. Tripathi, and M. Inouhe, "Impacts of flyash on soil and plant responses," Journal of Plant Research, vol. 115, no. 6, pp. 401-409, 2002.

[16] V. C. Pandey and N. Singh, "Impact of fly ash incorporation in soil systems," Agriculture, Ecosystems \& Environment, vol. 136, no. 1, pp. 16-27, 2010.

[17] P. Hartmann, H. Fleige, and R. Horn, "Changes in soil physical properties of forest floor horizons due to long-term deposition of lignite fly ash," Journal of Soils and Sediments, vol. 10, no. 2, pp. 231-239, 2009.

[18] A. Riehl, F. Elsass, J. Duplay, F. Huber, and M. Trautmann, "Changes in soil properties in a fluvisol (calcaric) amended with coal fly ash," Geoderma, vol. 155, no. 1-2, pp. 67-74, 2010.

[19] X. Wang, J. Yan, H. Yu, X. Dong, X. Chen, and C. Wang, "Experiment study on vertical movement feature of moisture in coal rejects layer of backfill reclamation land in mining area," Coal Engineering, vol. 45, no. 11, pp. 99-101+104, 2013.

[20] L. Xu, S. Xu, J. Yan et al., "Optimum soil coverage thickness of reclamation land filled with fiy ash," vol. 37, no. S2, pp. 485-488, 2012.

[21] H. Dang, M. Shao, H. Chen, and B. Zhou, "Effect of thickness and location of coal gangue on the process of water infiltration," Journal of Soil and Water Conservation, vol. 26, no. 3, pp. 62-66, 2012.

[22] H. H. Gerke, A. Badorreck, and M. Einecke, "Single-and dualporosity modelling of flow in reclaimed mine soil cores with embedded lignitic fragments," Journal of Contaminant Hydrology, vol. 104, no. 1-4, pp. 90-106, 2009.

[23] Y. Lu, "Compacting treatment affected to moisture content of coal rejected backfilling reclaimed land," Coal Science and Technology, vol. 38, no. 11, pp. 125-128, 2010.

[24] Z. Zhang, W. Sui, K. Wang, G. Tang, and X. Li, "Changes in particle size composition under seepage conditions of reclaimed soil in Xinjiang, China," Processes, vol. 6, 10 pages, 2018.

[25] Z. Zhang, G. Tang, and J. Zhu, "Study on compaction of reclaimed soil of nonmetallic mining area in northern foothills of tianshan mountains in Xinjiang, China," Advances in Materials Science and Engineering, vol. 2019, Article ID 2834019, 10 pages, 2019.

[26] X. Li, "Preliminary studying the characteristic of roots and relactions between roots and environment of ephemerals in Xinjiang," Arid zone research, vol. 17, no. 3, pp. 28-34, 2000.

[27] H. Sun, R. Wu, P. Li, S. Shao, L. Qi, and J. Han, "Rooting depth of alfafa," Acta Agrestia Sinica, vol. 3, pp. 307-312, 2008.

[28] X. Yang, X. Zhang, Y. Li, S. Li, and H. Sun, "Analysis of root architecture and root adaptive strategy in the taklimakan desert area of China," Journal of Plant Ecology, vol. 6, pp. 1268-1276, 2008. 